\title{
First record of the freshwater bryozoan Pectinatella magnifica in north-west Russia with a description of sensory structures
}

\author{
Z.I. Starunova ${ }^{1}$, K.V. Shunkina ${ }^{1}$, E.A. Genelt-Yanovsky ${ }^{2}$, \\ A.V. Kucheryavyy ${ }^{3}$, N.V. Polyakova ${ }^{3}$, Y.A. Danilova ${ }^{4}$, T.A. Ivanova ${ }^{4}$, \\ V.V. Starunov ${ }^{1,5}$, O.V. Zaitseva ${ }^{1 *}$ \\ ${ }^{1}$ Laboratory of Evolutionary Morphology, Zoological Institute, Russian Academy of Sciences, \\ Universitetskaya nab. 1, Saint Petersburg 199034, Russia.E-mails: Zinaida.Starunova@zin.ru, \\ Ksenia.Shunkina@zin.ru \\ ${ }^{2}$ Department of molecular systematics, Laboratory of Theriology, Zoological Institute, Russian \\ Academy of Sciences, Universitetskaya nab. 1, Saint Petersburg 199034, Russia. E-mail: \\ Evgeny.Genelt-Yanovskiy@zin.ru \\ ${ }^{3}$ Laboratory of behavior of lower vertebrates, A.N. Severtsov Institute of Ecology and Evolution, \\ Russian Academy of Sciences, Leninskypr.33,Moscow, 119071 Russia.E-mails: scolopendra@bk.ru, \\ nvpnataly@yandex.ru \\ ${ }^{4}$ Baltic Fund for Nature (ICPO Biologists for nature conservation), 24 liniya V.O. 3-7, Saint- \\ Petersburg,Russia.E-mails: suillus@mail.ru,ivanova.baltic@gmail.com \\ ${ }^{5}$ Department of Invertebrate Zoology, Faculty of Biology, Saint Petersburg State University, \\ Universitetskaya nab.7/9, Saint Petersburg, 199034 Russia.E-mail: Victor.Starunov@spbu.ru \\ * Corresponding author: ovzaitseva@inbox.ru
}

ABSTRACT: Colonies of the freshwater bryozoan Pectinatella magnifica (Leidy, 1851) were found in north-west Russia for the first time. As the colonies have been observed in Vuoksi river connecting Saimaa and Ladoga lakes, most likely this is a result of the downstream migration from Finland. Details of the general morphology of $P$. magnifica and distribution of sensory structures on the lophophore and colony surface were studied using scanning electron microscopy. Three types of sensory structures were recorded. Two rows of presumably immobile cilia were found on the latero-frontal surfaces of tentacles, and this type is common in Bryozoa. One-two sensory cilia with bases surrounded by short microvilli were detected on the abfrontal surface of the tentacles as well as on the outer and inner surfaces of the lophophoral arms. The mechanosensory function of both these types was assumed like in other bryozoans. Sensory structures of the third type were microvillous 'knobs' situated on the colonial body wall surface. They were described for the first time in Bryozoa. Their possible photosensory function is discussed.

How to cite this article: Starunova Z.I., Shunkina K.V., Genelt-Yanovsky E.A., Kucheryavyy A.V., Polyakova N.V., Danilova Y.A., Ivanova T.A., Starunov V.V., Zaitseva O.V. 2021. First record of the freshwater bryozoan Pectinatella magnifica in north-west Russia with a description of sensory structures // Invert. Zool. Vol.18. No.3. P.355-368. doi: 10.15298/invertzool.18.3.09

KEY WORDS: aquatic invasion, freshwater Bryozoa, sensory structures, scanning electron microscopy.

The paper is devoted to 70th anniversary of Prof. V.V. Malakhov.

Статья посвящена 70-летию со дня рождения проф., акад. В.В. Малахова. 


\title{
Первая находка пресноводной мшанки Pectinatella magnifica на северо-западе России с описанием сенсорных структур
}

\author{
3.И. Старунова ${ }^{1}$, К.В. Шунькина ${ }^{1}$, Е.А. Генельт-Яновский ${ }^{2}$, \\ А.В. Кучерявый ${ }^{3}$, Н.В. Полякова ${ }^{3}$, Ю.А. Данилова ${ }^{4}$, Т.А. Иванова ${ }^{4}$, \\ В.В. Старунов ${ }^{1,5}$, O.В. Зайцева ${ }^{1 *}$
}

\begin{abstract}
${ }^{1}$ Лаборатория эволючионной морфологии, Зоологический институт Российской академии наук, Университетская наб., 1, Санкт-Петербург, 199034 Pоссия. E-mails: Zinaida.Starunova@zin.ru, Ksenia.Shunkina@zin.ru

${ }^{2}$ Отделение молекулярной систематики, Лаборатория териологии, Зоологический институт Российской академии наук, Университетская наб., 1, Санкт-Петербург, 199034 Росcия. E-mail: Evgeny.Genelt-Yanovskiy@zin.ru

3 Лаборатория поведения низших позвоночных, Институт проблем экологии и эволючии им. А.Н. Севериова Российской академии наук, Ленинский проспект 33, Москва, 119071 Россия. E-mails: scolopendra@bk.ru,nvpnataly@yandex.ru

${ }^{4}$ Балтийский фонд природы (МБОО Биологи за охрану природы), 24-я линия В.О. 3-7, СанктПетербург, Россия.E-mail: suillus@mail.ru,ivanova.baltic@gmail.com

${ }^{5}$ Кафедра зоологии беспозвоночных, Биологический факультет, Санкт-Петербургский гос. университет, Университетская наб., 7/9, Санкт-Петербург, 199034 Россия.

* Адрес для корреспондениии: ovzaitseva@inbox.ru
\end{abstract}

РЕЗЮМЕ: Колонии пресноводной мшанки Pectinatella magnifica (Leidy, 1851) были впервые обнаружены на северо-западе России. Поскольку колонии обнаружены в реке Вуокса, соединяющей озера Сайма и Ладога, скорее всего, это результат миграции с территории Финлядии. Детали общей морфологии и распределение сенсорных структур на лофофоре и поверхности колонии P. magnifica были изучены с помощью сканирующей электронной микроскопии. На поверхности зооидов и колонии были обнаружены три типа сенсорных структур. Два продольных ряда, предположительно неподвижных ресничек, были обнаружены на латеро-фронтальных поверхностях щупалец и типичны для мшанок в целом. Одна-две сенсорные реснички, окруженные короткими микровиллями находятся на абфронтальной поверхности щупалец, особенно в их основании, а также на фронтальной и абфронтальной поверхностях рук лофофора. По аналогии с другими видами мшанок предполагается механосенсорная функция этих структур. Третий тип сенсорных структур представляет собой микровиллярный бугорок и был обнаружен на поверхности стенки колонии и описан впервые для пресноводных мшанок. Для этого типа нами рассматривается возможная фотосенсорная функция.

Как цитировать эту статью: Starunova Z.I., Shunkina K.V., Genelt-Yanovsky E.A., Kucheryavyy A.V., Polyakova N.V., Danilova Y.A., Ivanova T.A., Starunov V.V., Zaitseva O.V. 2021. First record of the freshwater bryozoan Pectinatella magnifica in north-west Russia with a description of sensory structures // Invert. Zool. Vol.18. No.3. P.355-368. doi: 10.15298/invertzool.18.3.09

КЛЮЧЕВЫЕ СЛОВА: водные инвазии, пресноводные мшанки, сенсорные структуры, сканирующая электронная микроскопия. 


\section{Introduction}

Bryozoans are aquatic sessile colonial invertebrates that occupy various substrates and play an important role in benthic communities (Wood, Okamura, 2005; Schwaha, 2021). Phylum Bryozoa comprises of three classes, Gymnolaemata, Stenolaemata and Phylactolaemata. All Stenolaemata and most Gymnolaemata are marine, while Phylactolaemata are exclusively freshwater. Whereas feeding and behavior was described in many marine bryozoans (reviewed in Winston, 1977, 1978; Ostrovsky, Shunatova, 2002; Ostrovsky et al., 2002; Winston, Migotto, 2021), relatively few studies were specifically focused on the freshwater species (Antipenko, 1999; Riisgård et al., 2004, 2010; Tamberg et al., 2014; Tamberg, Shunatova, 2016).

Research on the mechanisms of bryozoan feeding and accompanying phenomena (e.g. Riisgård, Manríques, 1997; Shunatova, Ostrovsky, 2001, 2002; Riisgård et al., 2010) triggered the renewed interest to the studies of the nervous system and sensory structures (e.g. Schwaha, Wanninger, 2012; Temereva, Kosevich, 2016, 2018; Shunkina et al., 2015; Shunkina, Zaitseva, 2017; Worsaae et al., 2019, reviewed in Schwaha et al. 2020). Although first observations of putative sensory structures on bryozoan tentacles go back to the first half of the XIX century (Lister, 1834), and this work was continued after invention of the histological staining technique (e.g. Silbermann, 1906; Gerwerzhagen, 1913; Lutaud, 1955; Brien, 1960), information on this topic was generally scant till recent (reviewed in Winston, 1978; Ostrovsky, Shunatova, 2002). Invention of the scanning and transmission electron microscopy (SEM and TEM elsewhere in the text) and modern staining techniques (among them glyoxylic acidinduced fluorescence) greatly added to our understanding of the bryozoan sensory structures (e.g. Gilmour, 1978; Nielsen, Riisgård, 1998; Shunatova, Nielsen, 2002; Riisgård et al., 2004, 2010; Shunkina et al., 2014a; 2015; Shunkina, Zaitseva, 2017; Tamberg, Shunatova, 2017). Currently, ciliary cells with presumed sensory function are known on the tentacles and the introvert (eversible part of the body wall) in both marine and freshwater bryozoans.

The freshwater bryozoan "jelly brain" Pectinatella magnifica (Leidy, 1851), is a widespread North American species actively spreading across Europe in during recent decades including Danube (Szekeres et al., 2013), Elbe (Balounová, et al., 2011) and other river systems. In 2010 P. magnifica was noticed in the lake Saimaa (Finland) near the border with Russia(I.Kuznetsov, personal communication). Vuorio with co-authors (2018) described the invasion history and dispersion of $P$. magnifica in Finland suggesting that this species has been most likely introduced by international shipping 10-15 years ago. Here we report the first finding of $P$. magnifica in the Vuoksi river, and describe its general morphology and sensory structures on the surface of the lophophore (feeding apparatus) and the colony wall.

\section{Materials and Methods}

Colonies of Pectinatella magnifica (Fig. 1A, B) were collected in July-August 2020 from single location at Vuoksi-Virta (location coordinates $60.75,29.78$ ). Colonies were abundant at sites with slow water flow and up to 23 meters deep, usually near the water surface, being attached to rigid stems of aquatic macrophyte vegetation like Phragmites australis, Potamogeton natans, Eleocharis spp. mostly along the shore region.

Species identification was carried out based on general morphology of the colony, zooidal and statoblasts morphology using guidebooks (Kluge, 1949; Lacourt, 1968; Gontar, 2012). Colonies were photographed using Olympus OM-D E-M5 II digital camera, and colony details were further studied using stereomicroscope Leica M205C equipped with a Leica DFS405 camera.

For scanning electron microscopy, the groups of zooids without gelatinous mass were dissected from colony, relaxed by adding drop by drop $7 \%$ solution of $\mathrm{MgCl}_{2}$, and fixed in $1.25 \%$ glutaraldehyde in $0.05 \mathrm{M}$ phosphate buffer (PB, $\mathrm{pH}$ 7.2). After fixation, the specimens were rinsed 1-3 times in PBS and dehydrated in an 

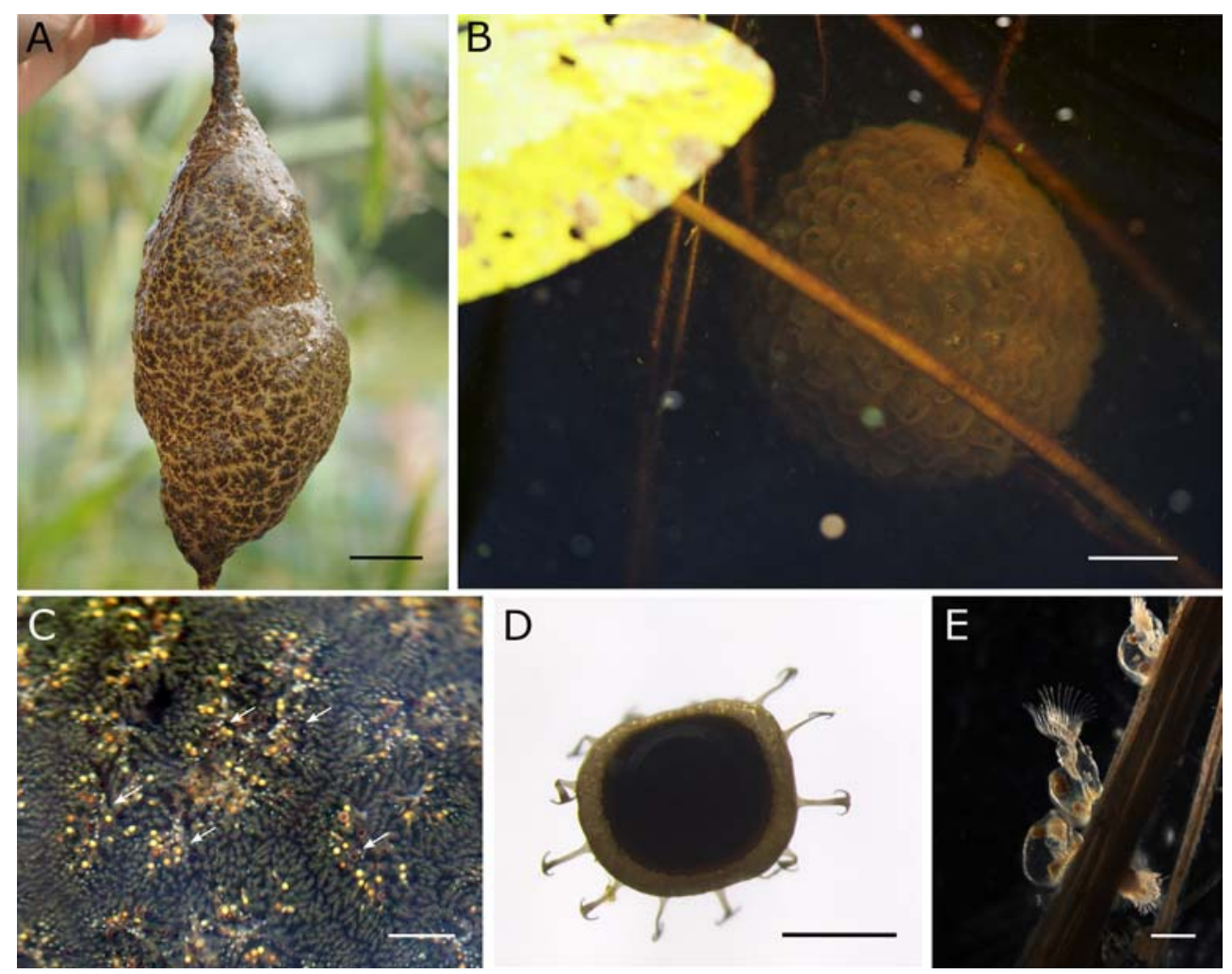

Fig. 1. Freshwater bryozoan Pectinatella magnifica found in Vuoksi-Virta, Leningrad oblast, Russia. A colony pulled out of the water; $\mathrm{B}$ - submerged colony; $\mathrm{C}$ - part of the colony with expanded lophophores and statoblasts (arrows) visible inside colony; D - statoblast; E - young colonies developed from statoblasts (photo by V. Khabibulina).

Scale bars: A, B $-3 \mathrm{~cm}$; C, D $-0.5 \mathrm{~cm}$; E $-0.1 \mathrm{~cm}$.

Рис. 1. Пресноводная мшанка Pectinatella magnifica из Вуокса-Вирта, Ленинградская область, Россия. А - общий вид колонии, извлеченной из воды; В - общий вид колонии под водой; $\mathrm{C}-$ часть колонии с лофофорами и статобластами (отмечены стрелками); D — статобласт; Е — молодые колонии, развивающиеся из статобластов (фото В. Хабибулиной).

Масштаб: А, В - 3 см; C, D-0,5 см; E-0,1 см.

acetone series of increasing concentration, critical point dried, coated with platinum, and examined under a FEI Quanta 250 scanning electron microscope (FEI Company, The Netherlands). Measurements were performed (not less than 10 measurements for each type of cells and cilia) using Fiji (Schindelin et al, 2012).

\section{Results}

The observed colonies of Pectinatella magnifica were fusiform or spherical (Fig. 1A, B), attaching to various aquatic vegetation, tree branches or, sometimes, stones. They were 10$30 \mathrm{~cm}$ in length/diameter, the largest having a weight up to 2 kilograms. The gelatinous mass covered by hundreds of 'rosettes' of various forms, each formed by several zooids (Fig .1C). Formation of the dormant asexual stage (statoblasts) began in August. Statoblasts have a round shape and one row of anchor-like thorns around the edge of the disc (Fig. 1D). Colonies disappeared at the end of the summer. Under laboratory conditions it was possible to grow young colonies (Fig. 1E) from the statoblasts without freeze-thawing cycle. 
Zooids of Pectinatella magnifica have a massive horseshoe crown of tentacles (lophophore) consisting of two arms bearing 40-50 ciliated tentacles (Fig. 2A, B). Each tentacle possesses tree ciliary bands: two lateral and one frontal with densely spaced motile cilia (Fig. 2C). Lateral multiciliary epithelial cells were about $4-5 \mu \mathrm{m}$ in diameter in fixed material and bore about 20 cilia, each about $15 \mu \mathrm{m}$ long (Fig. 2D). On either side of the frontal ciliary band the rows of latero-frontal cilia, presumably immobile, were situated (Fig. 2E, F). The bases of these cilia were surrounded by tiny folds that may presumably be interpreted as microvilli. We were not able to recognize the cell borders corresponding to them. Cilia of these cells were thinner towards the distal end and were longer than the cilia of the epithelial cells, reaching at least $20 \mu \mathrm{m}$ (Fig. 2F).

On the surface of the lophophore arms and abfrontal surfaces of the tentacles the borders of non-ciliated epithelial cells are clearly visible. The apical surfaces of these cells have an irregular polygonal shape being about $10-15 \mu \mathrm{m}$ in size (Fig. 3). Among them the ciliary cells (presumably sensory) were recorded on both the abfrontal surface of tentacles (Fig. 3C) and randomly on the outer (faced to outside) and inner (faced to another arm) surfaces of the lophophore arms. Apical surfaces of these cells were smaller in size than neighboring epithelial cells. They had an irregular triangle-like shape with size about 1-1.5 $\mu \mathrm{m}$ (Fig. 3A, B, D-G). These cells were mostly monociliated, but sometimes biciliated (Fig. $3 \mathrm{G}$ ) with a cilium $8-10 \mu \mathrm{m}$ long, having the same diameter along the entire length, and basal part surrounded by several short microvilli, about $0.5 \mu \mathrm{m}$ long (Fig. 3DG). Such cells were sometimes grouped by two (Fig. 3D), but most were single (Fig. 3E, F).

Epithelial cells of the introvert had an irregular shape being 20-30 $\mu \mathrm{m}$ in size (Fig. 4A-C), and bore no cilia or microvilli. Colony bodywall was composed of different-sized cells similar to the cells of an introvert. Among them some had microvillary apical surfaces that looked like knobs (size 5-7 $\mu \mathrm{m}$ ), densely covered with 1-2 $\mu \mathrm{m}$ long microvilli (Fig. 4D-F). They were sparsely spread on the colony wall being usually situated close to the bases of the introverts.

\section{Discussion}

\section{Lifespan and ways of invasion}

Invasions and distribution patterns of alien species affect local biodiversity and aquatic environments (Orlova et al., 2006). There are some possible ways how the recent invader Pectinatella magnifica could enter the Russian inland waters. According to the data from the Danube river and the known rate of invasion (Zorić et al., 2015), we would expect that $P$. magnifica could actively spread across the territory of Russia from the southern regions. Such an assumption was made by Kluge, who did not find Pectinatella in the former USSR, however (Kluge, 1949). In more recent list of bryozoan species of the Pontic-Caspian fauna, P. magnifica was mentioned among the freshwater bryozoans of the Danube-Don area (Vinogradov, 2003). However, our recent finding of $P$. magnifica in Vuoksi river system currently is the only record of this species in Russia.

Leningrad oblast at the north-west of Russia is known to be the gate for invasions by nonindigenous species. It is situated at the border of two climatic zones: subarctic and temperate being influenced by the temperate zone in summer and the subarctic in winter (Orlova et al., 2006). The Leningrad oblast and Saint Petersburg are also important transport shipping centers, and the ballast waters are one of the potential means of introduction of non-native aquatic species. All these factors may afford the alien species to spread into new areas and provide new opportunities for distribution of water animals.

Inland waters of Finland are not readily available for non-indigenous species because of low water $\mathrm{pH}$ and temperature and low nutrient concentrations. These conditions form natural barrier against invasions (Vuorio et al., 2018). According to Vuorio with co-authors, there are three main factors of the $P$. magnifica invasion in the Vuoksi River watercourse: the shipping 

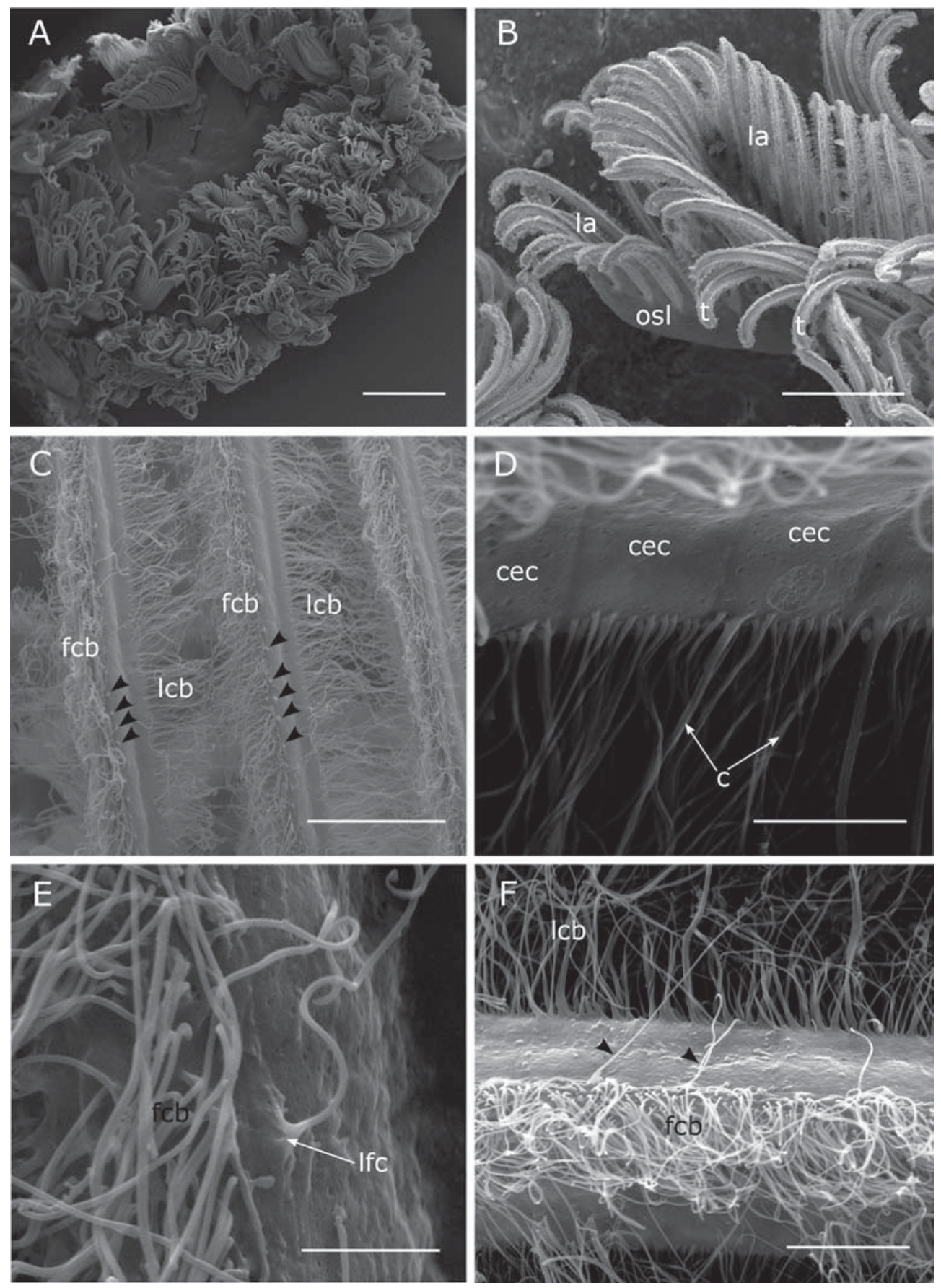

Fig. 2. Scanning electron micrographs of a colony fragment, lophophoral arms and tentacle surface in Pectinatella magnifica. A - general view of a colony fragment with expanded lophophores; B - part of horseshoe-shaped tentacular crown (lophophore); $\mathrm{C}$ - arrangement of ciliary bands on tentacles; D ciliary epithelial cells of lateral ciliary band (frontal ciliature in the upper part of image); E - close up of latero-frontal cilium near frontal ciliary band; F - latero-frontal cilia visible between frontal and lateral ciliary bands. Arrowheads indicate latero-fronrtal cilia. 
waterways, recreational boating, and the most likely water birds. The Vuoksi is running through two countries: Finland and Russia. There are three dams on it, one in Imatra (Finland) close to the border, two others in Russia. These dams prevent any shipment and recreational boating across the border. Thus, possible methods for migration of $P$. magnifica from Finland's part of the Vuoksi River to its Russian part is a statoblast transport by the water birds and the river flow itself. For instance, statoblasts of another freshwater bryozoan Cristatella mucedo were transported over long distances (more than 300 kilometers) in the digestive tract of waterfowl (Charalambidou et al., 2003).

Water temperature is one of the main environmental factors that control growth and reproduction of Pectinatella magnifica (Joo et al., 1992). Similar to all other freshwater bryozoans, it can survive winter only as a dormant stage (statoblasts). The temperature limitation for the growth and reproduction could be the possible explanation why the colonies occurred only at $3.5 \mathrm{~km}$ of the coastline in the semiisolated Vuoksi-Virta and the species was not observed in the most part of the $150 \mathrm{~km}$ riverbed of Vuoksi. Phylactolaemates in the Ukrainian part of the Danube River delta start to form new colonies at the beginning of the summer, and the destruction of the colonies begins in the second decade of October-November (Aleksandrov et al., 2014). In the Leningrad oblast, the duration of the colony life of C. mucedo is about the same (K. Shunkina, personal communication). Unfortunately, there are no data about timespan of the colonies of $P$. magnifica in Finland. Howev- er, according to our observations, it is noticeably shorter, possibly because of lower water temperature most of the year. Colonies of P. magnifica in the Leningrad oblast reach the size up to $30 \mathrm{~cm}$ in diameter in August but are found only during two summer months, and vanish before autumn. In other words, in the north-west Russia (and, obviously, Finland) for 10 months $P$. magnifica exists as statoblasts.

\section{Sensory structures}

Tentacles of Pectinatella magnifica, like those of the other phylactolaemates (Mukai et al., 1997; Riisgård et al., 2004, 2010; Shunkina et al., 2015; Tamberg, Shunatova, 2017), have three broad ciliary bands formed by multiciliary epithelial cells: one frontal and two lateral. The cilia are motile and generate water currents that deliver food particles to the mouth. The length of these cilia varies from 9 to $30 \mu \mathrm{m}$ in different bryozoan species. The average cilia length in $P$. magnifica is $15 \mu \mathrm{m}$. There are also two rows of latero-frontal cilia situated on either side of the frontal ciliary band (Figs 2C; 5). Although we were not able to recognize the cell borders around them, we believe that these cilia correspond to the latero-frontal monociliary cells known in the tentacles all bryozoans studied so far (reviewed in Mukai et al., 1997 and Ostrovsky et al., 2002).

Concerning phylactolaemates, initially monociliary "sensory cells" were described on the tentacles of Cristatella mucedo, Lophopus cristallinus and Plumatella fungosa using histological sections (Gerwerzhagen, 1913; Marcus, 1926a), and Brien (1960) was the first who

Abbreviations: c — cilia; cec — ciliary epithelial cells; fcb — frontal ciliary band; la — lophophoral arm; lcb — lateral ciliary band; lfc - latero-frontal cilia; osl - outer surface of lophophore; $\mathrm{t}$ - tentacles. Scale bars: A - $1 \mathrm{~mm}$; B $0.1 \mathrm{~mm} ; \mathrm{C}-30 \mu \mathrm{m} ; \mathrm{D}-5 \mu \mathrm{m} ; \mathrm{E}-3 \mu \mathrm{m} ; \mathrm{F}-10 \mu \mathrm{m}$.

Рис. 2. Фрагмент колонии, руки лофофора и поверхность щупалец у Pectinatella magnifica, сканирующая электронная микроскопия. А - общий вид участка колонии с лофофорами; В — часть подковообразного лофофора; C — расположение рядов ресничек на щупальцах; D — ресничные эпителиальные клетки латеральной ресничной полоски (сверху реснички фронтальной полоски); Е латерофронтальные реснички в фронтальных ресничных рядах; F — латерофронтальные реснички около фронтальной ресничной полоски. Реснички латеро-фронтальных рядов указаны стрелками. Обозначения: c - реснички; сес — ресничные эпителиальные клетки; fcb — фронтальный ресничный ряд; la руки лофофора; $1 \mathrm{cb}$ - латеральный ресничный ряд; $1 \mathrm{fc}$ - латеро-фронтальные реснички; оsl — внешняя поверхность лофофора; $\mathrm{t}$ - щупальца. Масштаб: A - 1 мм; B - 0,1 мм; C - 30 мкм; D - 5 мкм; E -3 мкм; $\mathrm{F}-10$ мкм. 

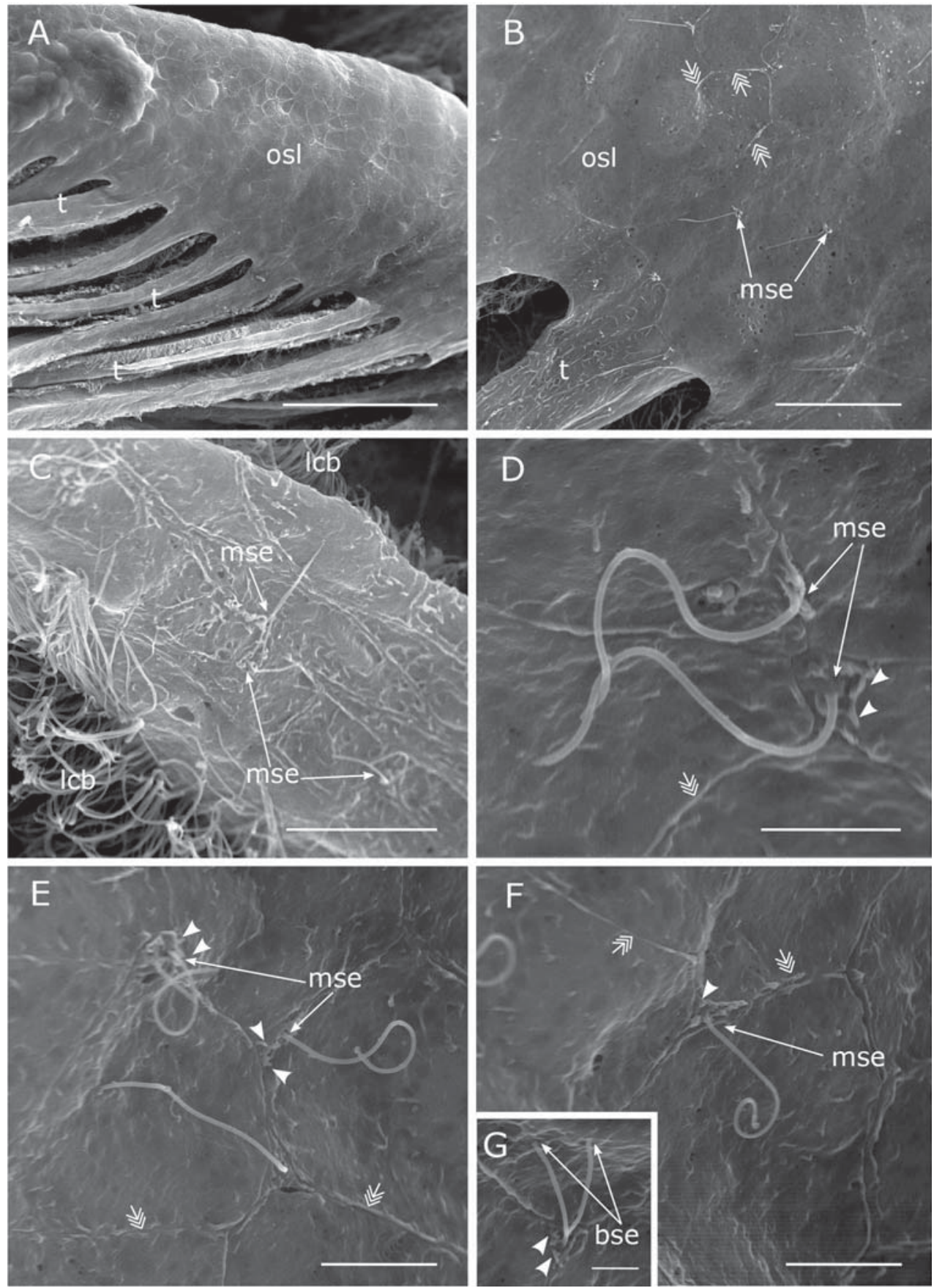

Fig. 3. Scanning electron micrographs of lophophoral arms and abfrontal tentacle surface with sensory structures in Pectinatella magnifica. A - basal part of lophophore arm with outer tentacle row; B - outer surface of the lophophore arm showing sensory cilia; C — cilia on abfrontal tentacle surface; D, E — close up of the second type of monociliary sensory structures on the outer surface of the lophophore arm; F — close up of inner surface of the lophophore arm with sensory structure; G - biciliary sensory structure. Arrowheads point to microvilli around the ciliary bases. Triple arrows show the borders of epithelial cells. 
precisely indicated their latero-frontal position. Gilmour (1978) found these cells in Plumatella sp. using transmission electron microscopy (TEM) and mentioned that the ciliary base is surrounded by rings of microvilli. He also wrote that basally the latero-frontal cells have "synapses with the nerves running along the tentacles" (p. 2152). This corresponds to the data of Shunkina with co-authors $(2014 b, 2015)$ on $C$. mucedo. According to this description the latero-frontal cells basally have axons extending into the latero-frontal nerves. The number of cilia was not indicated, however. TEM study by Tamberg \& Shunatova (2017) did not mention any connection between the latero-frontal cells and corresponding nerves below them in three studied phylactolaemates, however. Several SEM works showed the presence of the laterofrontal cilia in $P$. repens, $P$. fungosa, C. mucedo and Fredericella sultana. In all species the base of each cilium was surrounded by a circle of microvilli (Riisgård et al., 2004, 2010; Tamberg, Shunatova, 2017).

In P. magnifica the latero-frontal cells have a single cilium, each narrowed to the distal end, which is usually characteristic for the sensory cells (Croft et al., 2018). The presence of surrounding microvilli is also highly probable. However, the quality of material did not allow us to confirm or deny this suggestion without additional studies. Following previous authors, we suppose that latero-frontal monociliary cells have a sensory function (first type of sensory structures) in this species. In addition, study on feeding Plumatella repens (Riisgård et al., 2004) showed that stiff sensory latero-frontal cilia act as a mechanical sieve, as previously described in marine bryozoans (discussed in Riisgård et al., 2004 and Ostrovsky et al., 2002).

The second type of sensory structures was found in P. magnifica on the abfrontal surface of tentacles, as well as the outer and inner surfaces of the lophophore arms (Fig. 5). Each such structure includes 1-2 cilia surrounded by several microvilli and associated with a small area (1-1,5 $\mu \mathrm{m}$ in diameter) presumably representing an apical narrowed part of sensory cell(s) or its dendrite, also termed as sensory endings (Zaitseva, Bocharova, 1981; Schlawny, 1991a).

Both mono- and multiciliary cells with immobile cilia were described on the abfrontal tentacle side and introvert in marine Bryozoa (Shunatova, Nielsen, 2002; reviewed in Mukai et al., 1997 and Ostrovsky et al., 2002). In Stenolaemata all of them were monociliary, while in Gymnolaemata, bi- or multiciliary sensory cells alternate with monociliary ones (Shunatova, Nielsen, 2002). As to phylactolaemates, 5-10 pairs of 'setae' have been found on the abfrontal surface of the tentacles in $P$. repens (Bullivant, 1968) although SEM studies by Riisgård with co-authors (2004) revealed bundles of 4 cilia (surrounded by microvilli) in this species. Later on, presumed abfrontal sensory structures including 1-4 cilia (with the basal parts surrounded by microvilli visible on Fig. 8 , Riisgård et al., 2010) were described in $F$. sultana, L. cristallinus and C. mucedo. Single 'abfrontal cilia' were also illustrated by Gilmour (1978) who studied Plumatella sp. by TEM. Finally, TEM-study of Tamberg and Shunatova (2017) showed presence of the abfrontal ciliary

\footnotetext{
Abbreviations: bse — biciliated sensory structure; lcb — lateral ciliary band; mse — monociliary sensory structure; osl — outer surface of the lophophore arm; $\mathrm{t}$ - tentacles.

Scale bars: A $-100 \mu \mathrm{m} ; \mathrm{B}-20 \mu \mathrm{m} ; \mathrm{C}-10 \mu \mathrm{m} ; \mathrm{D}-3 \mu \mathrm{m} ; \mathrm{E}-5 \mu \mathrm{m} ; \mathrm{F}-5 \mu \mathrm{m}, \mathrm{G}-2 \mu \mathrm{m}$.

Рис. 3. Основание рук лофофора с сенсорными структурами у Pectinatella magnifica, сканирующая электронная микроскопия. А — основание лофофора и наружный ряд щупалец; В — поверхность рук лофофора с моноцилиарными клетками; C - реснички на абфронтальной поверхности щупалец; D, E - моноцилиарные сенсорные структуры второго типа на наружной поверхности рук лофофора; F внутренняя поверхность лофофора с сенсорными структурами; G - двуресничная сенсорная структура. Микроворсинки показаны наконечниками стрелок. Тройными стрелками показаны границы эпителиальных клеток.

Обозначения: bse - двуресничные сенсорные структуры; mse - моноцилиарные сенсорные структуры; оsl наружная поверхность лофофора; $\mathrm{t}$ - щупальца. Масштаб: A - 100 мкм; В - 20 мкм; C - 10 мкм; D - 3 мкм; $\mathrm{E}-5$ мкм; F - 5 мкм, G - 2 мкм.
} 

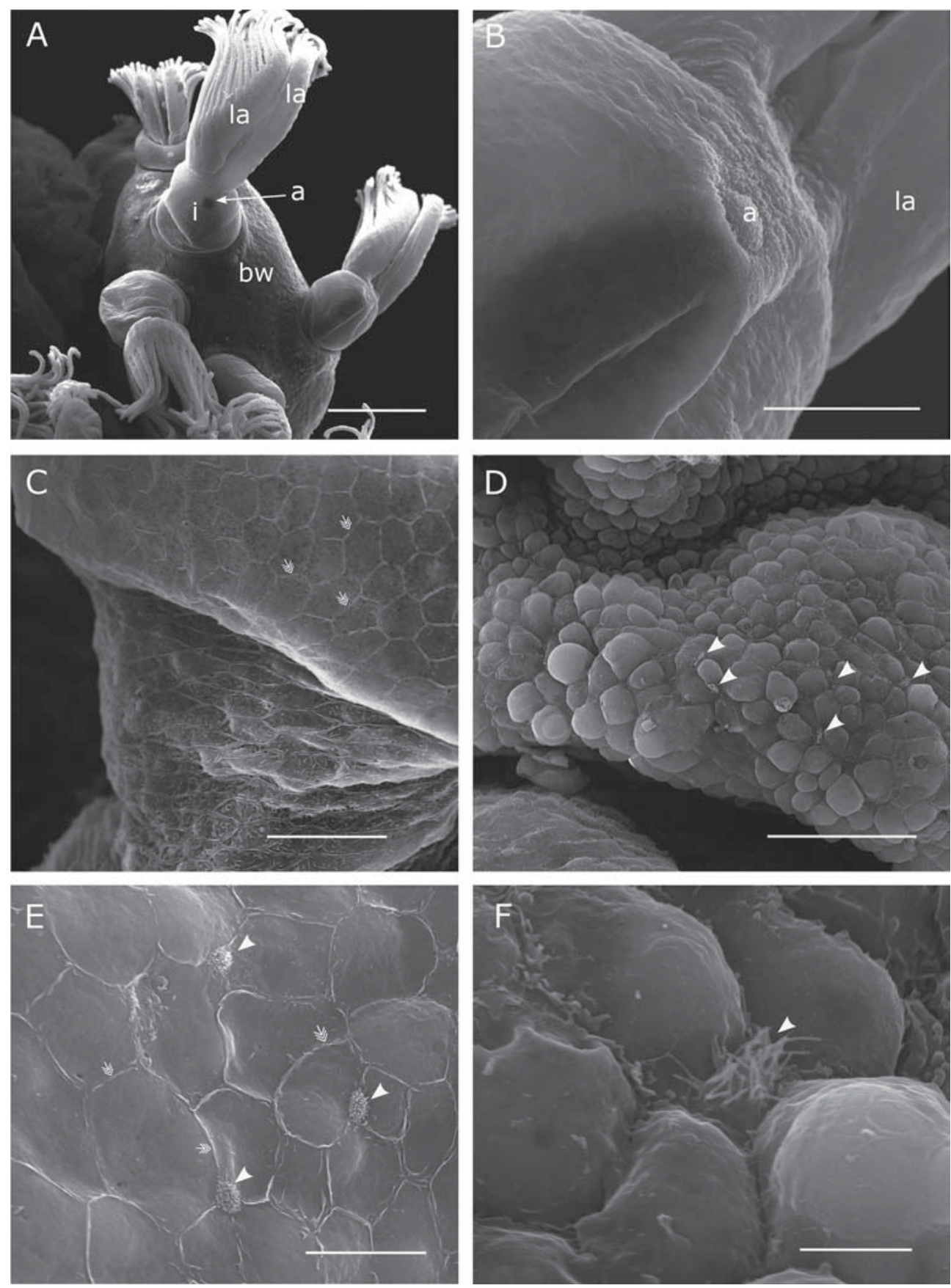

Fig. 4. Scanning electron micrographs of the colony surface and expanded lophophores in Pectinatella magnifica. A - general view of a part of the colony with protruded lophophores; B - part of lophophore viewed from the anal side; $\mathrm{C}$ - surface of introvert (above the lophophore arms); D, E, F - various magnifications of the third type of sensory structures (arrowheads) on the colony surface. Triple arrows show the borders of epithelial cells. 


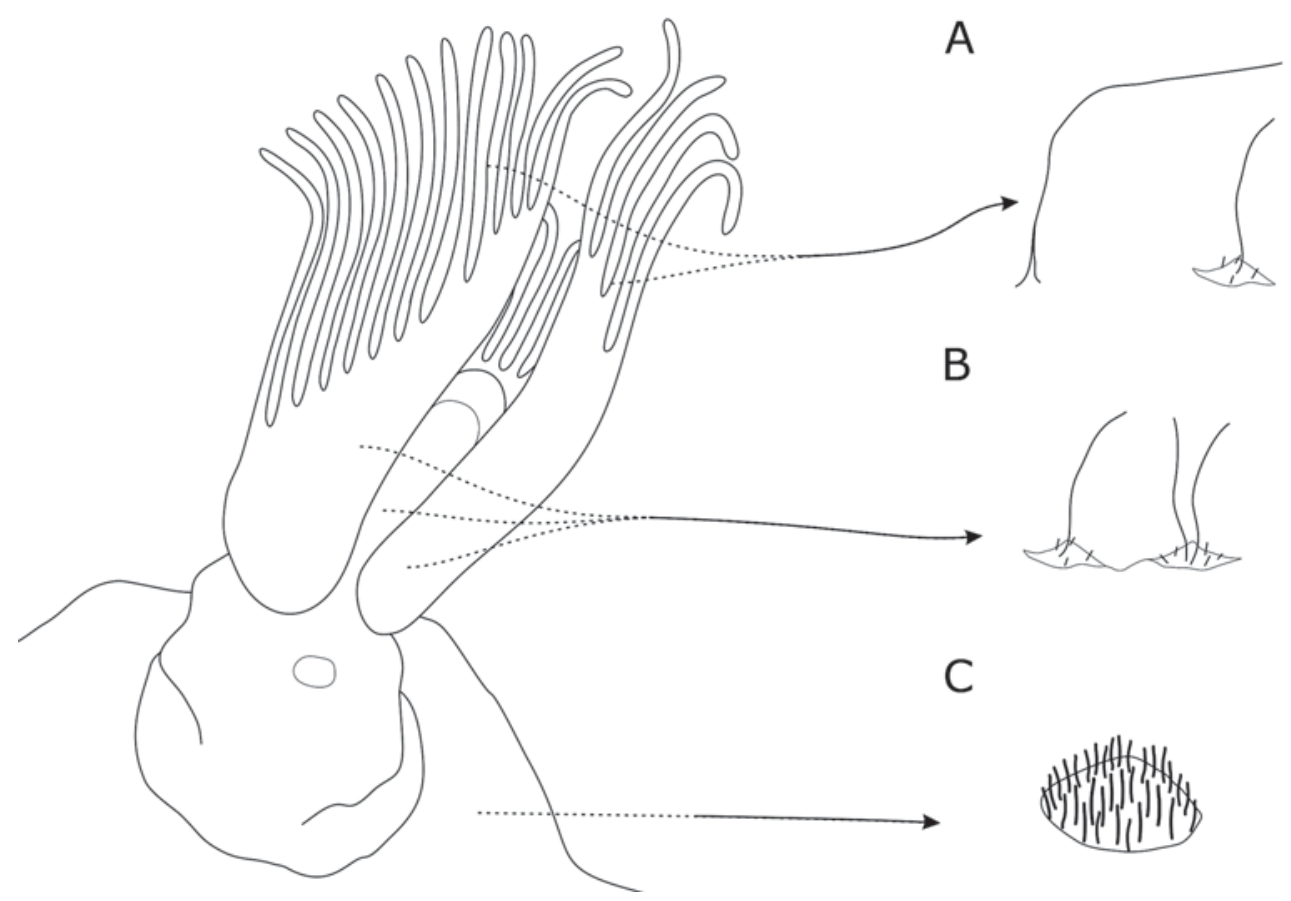

Fig. 5. Schematic drawings of three types of sensory structures in Pectinatella magnifica. A - first type on latero-frontal side of tentacles (from the left) and second type on abfrontal side of tentacles (from the right); $\mathrm{B}$ - second type on the lophophore; $\mathrm{C}$ - third type on the colony wall.

Рис. 5. Схема распределения трех типов сенсорных структур у Pectinatella magnifica. A 一 первый тип на латеро-фронтальной стороне щупалец (слева) и второй тип на абфронтальной стороне щупалец (справа); В - второй тип на внутренней и наружной сторонах рук лофофора; $\mathrm{C}$ - третий тип на стенке колонии.

'tufts' with microvillar ring around ciliary bases in P. fungosa, C. mucedo and F. sultana. Importantly, each such 'tuft' was formed by a pair of monociliated and/or biciliated cells that was considered as specific feature to Phylactolaemata. Mono- and/or biciliated, presumably sensory cells (never in pairs) with basal microvilli were also found externally on the intertentacular membrane in all three species studied. In contrast to all discussed examples, in
P. magnifica the abfrontal sensory cilia were usually single. In addition, they were situated not only on the abforntal side of the tentacles, but also on the outer and inner surface of the lophophore arms.

Observations and experiments on living bryozoans together with ultrastructural research led researchers to suggest that both latero-frontal and abfrontal sensory cells perceive tactile stimulation (Lutaud, 1955; Dick, 1984; Lutaud,

Abbreviations: a — anus; bw - body wall ; la - lophophoral arm; i — introvert. Scale bars: A - 500 $\mu \mathrm{m}$; B - 100 $\mu \mathrm{m} ; \mathrm{C}-40 \mu \mathrm{m} ; \mathrm{D}-50 \mu \mathrm{m} ; \mathrm{E}-20 \mu \mathrm{m} ; \mathrm{F}-5 \mu \mathrm{m}$.

Рис. 4. Общий вид поверхности колонии и расправленных лофофоров у Pectinatella magnifica, сканирующая электронная микроскопия. А - общий вид части колонии с расправленными лофофорами; В - участок лофофора и интроверт с анусом; С - поверхность интроверта (сверху руки лофофора); D, E, F — третий тип сенсорных структур (указаны при помощи наконечников стрелок) на поверхности колонии. Тройными стрелками показаны границы эпителиальных клеток.

Обозначения: a - анус; bw — стенка тела; la — руки лофофора; i — интроверт. Масштаб: A — 500 мкм; В 100 мкм; C - 40 мкм; D - 50 мкм; E - 20 мкм; F - 5 мкм. 
1993; Nielsen, Riisgård, 1998) thus being mechanosensory cells (discussed in Mukai et al. 1997). This is confirmed by the ultrastructural studies showing presence of the long rootlets of the cilia (Shunatova, Nielsen, 2002; Tamberg, Shunatova, 2017), which is one of the characteristic features for mechanoreception (Windoffer, Westheide, 1988). In addition, most of the tentacular sensory cilia in the studied bryozoans are immobile (but see Gordon 1974), which also testifies in favor to their mechanosensory function. Thus, it can be assumed that the sensory structures of the 1st and the 2nd types found in $P$. magnifica most likely belong to mechanosensory cells.

Behavioral experiments have shown that mechanical stimulation plays a more important role in the behavior of zooids than chemical (food) stimulation (Shunatova, Ostrovsky, 2001, 2002; Ostrovsky et al., 2002; Tamberg, Shunatova, 2016). Nevertheless, it is premature to assume that bryozoans have no chemical sensitivity (Shunatova, Ostrovsky, 2001). It has been shown that water quality as well as the concentration of oxygen and chlorophyll $\alpha$ play an important role in the distribution of $P$. magnifica. Also, this bryozoan tend to prefer certain plant species over others as a substrate for attachment (Joo et al., 1992; Vuorio et al., 2018). But if there is chemical sensitivity in bryozoans, what kind of sensory cells provide it?

The third type of the putative sensory structures was detected in P. magnifica on the colony wall surface near the base of the expanded lophophores. They have specialized microvillary knobs with diameter 5-7 $\mu \mathrm{m}$ (Figs 4D-F; 5 ), and have not been reported in bryozoans before. It is unlikely that these structures are mechanosensory since the such type of cells have cilia with a special rootlet system (Shunatova, Nielsen, 2002; Tamberg, Shunatova, 2017) or long stereocilia (as in the spiral organ of Corti) in both invertebrates and vertebrates (Schlawny, 1991a, b). Chemosensory function of the bryozoan colony wall is also unlikely, since chemoreception should most likely be used by lophophores to provide effective feeding and filtration by the tentacles. It should be noted that the structure of the sensory cells of $P$. magnifica colony wall is most similar to the photosensory cells of gastropods (Bobkova, 1998; Zaitseva, 1998, 2016). In addition, some freshwater bryozoans are known to be sensitive to light, although it is not clear how they can perceive it. For example, the mobile colonies of C. mucedo (Marcus, 1926b; Ryland, 1977; reviewed in Shunkina et al., 2015) and young colonies of P. magnifica (Joo et al., 1992) move away from the light and prefer the shady sides of substrates. In the attached bryozoan colonies, the photosensory cells of the colony wall can be involved in the regulation of seasonal or circadian biorhythms like in planktonic animals (Coesel et al., 2021). To answer this and other questions regarding the sensory system in Bryozoa, new studies are needed.

\section{Acknowledgments}

We are grateful to A.A. Petrov (Zoological Institute RAS) for reading the text of the manuscript. The research was completed using equipment of the Core Facilities Centre "Taxon", Zoological Institute of Russian Academy of Sciences (Saint Petersburg, Russia). This study was supported by budget funding No. AAAAA19-119020690076-7 at the Zoological Institute of Russian Academy of Sciences.

Conflict of Interest. The authors declare that they have no conflict of interest.

\section{References}

Aleksandrov B., Voloshkevich O., Kurakin A., Rybalko A., Gontar V. 2014. The first finding of bryozoan Pectinatella magnifica (Lophopodidae) in lower Danube // Vestn. Zool. Vol.48. No.4. P.307-312.

Antipenko I.I. 1999. [Peculiarities of feeding behaviour of Cristatella mucedo (Phylactolaemata: Bryozoa)] // Zhurn. Obsh. Biol. Vol.60. P.109-117 [in Russian].

Balounová Z., Rajchard J., Švehla J., Šmahel L. 2011. The onset of invasion of bryozoan Pectinatella magnifica in South Bohemia (Czech Republic) // Biologia. Vol.66. P.1091-1096.

Bobkova M.V. 1998. [Structural and functional organization of the peripheral part of the visual sensory system of the great pond snail Lymnaea stagnalis] // Zhurn. Evol. Biokhim. Fiziol. Vol.34. No.6. P.716-731 [in Russian]. 
Brien P. 1960. Classe des Bryozoaires // P.-P. Grassé (ed.). Traité de Zoologie. Paris: Masson. P.1053-1379.

Bullivant J.S. 1968. The method of feeding of lophophorates (Bryozoa, Phoronida, Brachiopoda) // New Zeal. J. Mar. Fresh. Vol.2. No.1. P.135-146.

Charalambidou I., Santamaria L., Langevoord O. 2003. Effect of ingestion by five avian dispersers on the retention time, retrieval and germination of Ruppia maritima seeds // Funct. Ecol. Vol.17. P.747-753.

Coesel S.N., Durham P., Groussman D., Hu S. K., Caron D.A., Morales R.L., Ribalet F., Armbrust E.V. 2021. Diel transcriptional oscillations of light-sensitive regulatory elements in open-ocean eukaryotic plankton communities // PNAS. Vol.118. No.6. P.1-12.

Croft J.T., Radhika D.Z., Subramanian R., Höög J.L. 2018. Composition, structure and function of the eukaryotic flagellum distal tip // Essays Biochem. Vol.62. P.815-828.

Dick M.H. 1984. Bryozoan behavior in relation to autocleaning in Holoporella brunea (Hincks) // Northwest Sci. Vol.58. No.3. P.195-207.

Gerwerzhagen A. 1913. Beiträge zur Kenntnis der Bryozoen. 1. Das Nervensystem von Cristatella mucedo Cuv // Z. Wiss. Zool. Bd.107. S.309-345.

Gilmour T.H.J. 1978. Ciliation and function of the foodcollecting and waste-rejecting organs of lophophorates // Can. J. Zool. Vol.56. P.2142-2155.

Gontar V.I. 2012. [Bryozoans of continental waters. Appendix 3] // A.A. Protasov, A.A. Silaeva (eds.). Contour grouping of hydrobionts in the techno-ecosystems TPS and NPS. Kyiv: Institute of Hydrobiology of Ukrainian NAS. P.248-261 [in Russian].

Gordon D.P. 1974. Microarchitecture and function of the lophophore in the bryozoan Criptosula pallasiana // Mar. Biol. Vol.27. P.147-163.

Joo G.-J., Ward A.K., Ward G.M. 1992. Ecology of Pectinatella magnifica (Bryozoa) in an Alabama Oxbow Lake: Colony Growth and Association with Algae // J. N. Am. Benthol. Soc. Vol.11. No.3. P.324-333.

Kluge G.A. 1949. [Chapter 13. Bryozoans (Bryozoa)] // V.I. Zhadin, E.N. Pavlovsky (eds.). Zhizn presnykh vod. Moskva, Leningrad: AN SSSR Publ. Vol.2. P.200 212 [in Russian].

Lacourt A.W. 1968. A monograph of the freshwater Bryozoa (Phylactolaemata) // Zool. Verh. Vol.93. P.1-159.

Lister J.J. 1834. Some observations on the structure and functions of tubular and cellular polypi, and of Ascidiae // Phil. Trans. R. Soc. London. Vol.1. P.365-388.

Lutaud G. 1955. Sur la ciliature du tentacule chez Ies Bryozoaires Chilostomes // Arch. Zool. Exp. Gen. Vol.92. P.13-19.

Lutaud G. 1993. L'innervation sensorielle du lophophore et de la région orale chez les Bryozoaires Cheilostomes // Ann. Sci. Nat. Zool. Vol.13. Ser.14. P.137-146.

Marcus E. 1926a. Beobachtungen und Versuche an lebeden Meeresbryozoen // Zool. Jahrb. Abt. Syst. Okol. Geogr. Tiere. Bd.52. S.1-102.

Marcus E. 1926b. Bryozoa // G. Grimpe, E. Wagler (Hrsg.). Die Tierwelt der Nord und Ostsee. Leipzig: AVG. Bd.4. S.1-100.
Mukai H., Terakado K., Reed C.G. 1997. Bryozoa // F.W. Harrison (ed.). Microscopic anatomy of invertebrates. Vol.13. New York: Wiley\&Liss. P. 45-206.

Nielsen C., Riisgård H.U. 1998. Tentacle structure and filter-feeding in Crisia eburnea and other cyclostomatous bryozoans, with a review of upstream-collecting mechanisms // Mar. Ecol. Prog. Ser. Vol.168. P.163-86.

Orlova M.I., Telesh I.V., Berezina N.A., Antsulevich A.E., Maximov A.A., Litvinchuk L.F. 2006. Effects of nonindigenous species on diversity and community functioning in the eastern Gulf of Finland (Baltic Sea) // Helgoland Mar. Res. Vol.60. P.98-105.

Ostrovsky A.N., Shunatova N.N., Antipenko I.I. 2002. Historical review on individual autozooidal behavior and feeding mechanisms in Bryozoa // P.N. Wyse Jackson, M.E. Spencer Jones (eds.). Annals of bryozoology: aspects of the history of research on bryozoans. Dublin: International Bryozoology Association. P.201228.

Ostrovsky A.N., Shunatova N.N. 2002. Colonial behavior and group zooidal reactions // P.N. Wyse Jackson, M.E. Spencer Jones (eds.). Bryozoa: history of the research. Annals of bryozoology: aspects of the history of research on bryozoans. Dublin: International Bryozoology Association. P.185-200.

Riisgård H.U., Nielsen K.K., Fuchs J., Rasniussen B.F., Obst M., Funch P. 2004. Ciliary feeding structures and particle capture mechanism in the freshwater bryozoan Plumatella repens (Phylactolaemata) // Invert. Biol. Vol.123. P.156-167.

Riisgård H.U., Okamura B., Funch P. 2010. Particle capture in ciliary filter-feeding gymnolaemate and phylactolaemate bryozoans - a comparative study // Acta Zool. Vol.91. P.416-425.

Riisgård H.U., Manríquez P. 1997. Filter-feeding in fifteen marine ectoprocts (Bryozoa): particle capture and water pumping // Mar. Ecol. Prog. Ser. Vol.154. P.223-239.

Ryland J.S. 2005. Bryozoa: an introductory overview // E. Wöss (ed.) Moostiere (Bryozoa). Linz: Oberösterreichisches Landesmuseum. Denisia. N.S.28. Vol.16. P.9-20.

Schindelin J., Arganda-Carreras I., Frise E., Kaynig V., Longair M., Pietzsch, Preibisch S., Rueden C., Saalfeld S., Schmid B., Tinevez J.-Y., White D.J., Hartenstein V., Eliceiri K., Tomancak P., Cardona A. 2012. Fiji: an open-source platform for biological-image analysis // Nat. Meth. Vol.9. No.7. P.676.

Schlawny A., Griinig C., Pfannenstiel H.-D. 1991a. Sensory and secretory cells of Ophryotrocha puerilis (Polychaeta) // Zoomorphology. Vol.110. P.209-215.

Schlawny A., Hamann T., Miiller M.A., Pfannenstiel H.D. 1991b. The catecholaminergic system of an annelid, Ophryotrocha puerilis (Polychaeta) // Cell Tiss. Res. Vol.265. P.175-184.

Schwaha T.F. (ed.). Handbook of Zoology. Phylum Bryozoa. Berlin: De Gruyter. 444 p.

Schwaha T.F., Ostrovsky A.N., Wanninger A. 2020. Key novelties in the evolution of Bryozoa: evidence from 
the soft-body morphology // Biol. Rev. Vol.95. No.3. P.696-729.

Schwaha T., Wanninger A. 2012. Myoanatomy and serotonergic nervous system of plumatellid and fredericellid Phylactolaemata (Lophotrochozoa, Ectoprocta) // J. Morphol. Vol.273. P.57-67.

Silbermann S. 1906. Untersuchungen über den feineren Bau von Alcyonidium mytili // Arch. Naturgesch. Bd.72. S.265-231.

Shunatova N.N., Nielsen C. 2002. Putative sensory structures in marine bryozoans // Invert. Biol. Vol.12. No.13. P.262-270.

Shunatova N.N., Ostrovsky A.N. 2001. Individual autozooidal behavior and feeding in marine bryozoans // Sarsia. Vol.86. P.113-142.

Shunatova N.N., Ostrovsky A.N. 2002. Group behavior and chimneys in marine bryozoans // Mar. Biol. Vol.140. P.503-518.

Shunkina K.V., Starunov V.V., Zaytseva O.V., Ostrovsky A.N. 2014a. [Comparative neuromorphology of the lophophore and body wall in three species of freshwater bryozoans (Bryozoa, Phylactolaemata)] // Zool. Zhurn. Vol.93. P.497-507 [in Russian, with English summary].

Shunkina K.V., Starunov V.V., Zaytseva O.V., Ostrovsky A.N. 2014b. Sensory elements and innervation in the freshwater bryozoan Cristatella mucedo lophophore // Dokl. Biol. Sci. Vol.455. P.125-128.

Shunkina K.V., Zaytseva O.V., Starunov V.V., Ostrovsky A.N. 2015. Comparative morphology of the nervous system in three phylactolaemate bryozoans // Front. Zool. Vol.12. P.1-28.

Shunkina K.V., Zaitseva O.V. 2017. Monoamines and neuropeptides in Bryozoa: localisation and possible functions // Invert. Zool. Vol.14. No.1. P.67-72.

Szekeres J., Akac A., Csanyi B. 2013. First record of Pectinatella magnifica (Leidy, 1851) in Hungary // Water Res. Manag. Vol.3. P.47-49.

Tamberg Y.Y., Shunatova N.N., Lezin P.A. 2014. [Feeding behaviour of freshwater bryozoans Cristatella mucedo and Plumatella fungosa (Bryozoa, Phylactolaemata)] // Zool. Zhurn. Vol.93. No.3. P.1-11 [in Russian].

Tamberg Y., Shunatova N. 2017. Tentacle structure in freshwater bryozoans // J. Morphol. Vol.278. No.5. P.718-733.

Tamberg Y., Shunatova N. 2016. Feeding behavior in freshwater bryozoans: function, form, and flow // Invert. Biol. Vol.135. No.2. P.138-149.

Temereva E.N., Kosevich I.A. 2016. The nervous system of the lophophore in the ctenostome Amathia gracilis provides insight into the morphology of ancestral ectoproct and the monophyly of the lophophorates // BMC Evol. Biol. Vol.16. No.181. P.24.

Temereva E.N., Kosevich I.A. 2018. The nervous system in the cyclostome bryozoan Crisia eburnea as revealed by transmission electron and confocal laser scanning microscopy // Front. Zool. Vol.15. P.48.

Vinogradov A.V. 2003. [Fauna of bryozoans (Eurystomata + Phylactolaemata) of Ponto-Caspian brackish water area] // Izv. Samarsk. Nauch. Tsentra RAN. Vol.5. No.2. P.256-267 [in Russian].

Vuorio K., Kanninen A., Mitikka S., Sarkkinen M., Hämäläinen H. 2018. Invasion of Finnish inland waters by the alien moss animal Pectinatella magnifica Leidy, 1851 and associated potential risks // Manag. Biol. Invas. Vol.9. No.1. P.1-10.

Windoffer R., Westheide W. 1988. The nervous system of Dinophilus gyrociliatus (Annelida: Polychaeta). I. Number, types and distribution pattern of sensory cells // Acta Zool. Vol.69. P.55-64.

Winston J.E. 1977. Feeding in marine bryozoans // R.M. Woollacott, R.L. Zimmer (ed.). Biology of bryozoans. New York, San Francisco, London: Academic Press. P.233-271.

Winston J.E. 1978. Polypide morphology and feeding behavior in marine ectoprocts // Bull. Mar. Sci. Vol.28. P.1-31.

Winston J.E., Migotto A.E. 2021. Behavior // T.F. Schwaha (ed.). Handbook of Zoology. Phylum Bryozoa. Berlin: De Gruyter. P.143-187.

Wood T.S., Okamura B. 2005. A key to the British and European freshwater bryozoans with ecological notes // Ambleside: Freshwater Biological Association, UK. Vol.63. P.1-113.

Worsaae K., Frykman T., Nielsen C. 2019. The neuromuscular system of the cyclostome bryozoan Crisia eburnea (Linnaeus, 1758) // Acta Zool. Vol.101. No.2. P.133-146.

Zaitseva O.V. 1998. Structure of sensory organs and skin innervation in the mollusc Pomacea paludosa (Prosobranchia) // J. Evol. Biochem. Physiol. Vol.34. No.3. P.233-242.

Zaitseva O.V. 2016. Stability, variability, and parallelisms in the development of distant sensory systems: olfactory and visual systems in the phylogeny and ontogeny of gastropods // Biol. Bull. Vol.43. No.3. P.195-207.

Zaiteva O.V., Bocharova L.S. 1981. Sensory cells in the head skin of pond snails. Fine structure of sensory endings // Cell Tiss. Res. Vol.220. P.797-807.

Zorić K., Szekeres J., Csányi B., Kolarevic S., Marković V., Paunović M. 2015. Distribution of the non-native bryozoan Pectinatella magnifca (Leidy, 1851) in the Danube River// Acta Zool. Bulg. Vol.67. P.241-247.

Responsible editor A.N. Ostrovsky 